\title{
Factors Related to Science Anxiety and Performance of Freshmen Laboratory High School Students of Naval State University, Naval, Biliran Province
}

\author{
Ruby Rose C. Besoyo ${ }^{\mathrm{a} *}$, Noel P. Tancinco ${ }^{\mathrm{b}}$ \\ College of Education, Naval State University, P.I. Garcia, Naval, Biliran Province 6560
}

\begin{abstract}
This study aimed to find out the factors related to science anxiety and performance of freshmen laboratory high school students of Naval State University. It involved three groups of respondents composed of 138 freshmen students, parents and teachers teaching science.The freshmen laboratory high school students were mostly female with the age of 13 years old. Their grade VI science grade ranged from 84-85; the entrance examination scores ranged from 30-34; and the attitudes profile of the respondents to science ranged from 4160.In the parents' profile, there were 43 families with an average of four children with a monthly average income of 5001-10,000. The parents' educational attainment showed that mostly of them were college degree holders. The teachers teaching style was democratic, and the result of the achievement test were satisfactory ranging from 21-30 while the level of anxiety was average, ranging from 51-75.Among the variables tested, the anxiety level of students and the profile of students in the terms of gender, Grade VI science grade, entrance examination, parents profile and science performance were found to be significantly related.
\end{abstract}

Key Terms:-Factors related to Science; Performance of Freshmen Students; Science Anxiety.

\section{INTRODUCTION}

Science is frequently perceived to be of great importance because of its link to technology and industry which, from a national perspective, maybe areas with high priority for development, Batomalaque(2009). Consequently, science is included as a core element in elementary and secondary levels of education despite conceptual complexity and high cost of implementation. Another justification for the inclusion of science in school curricula is that all citizens need to achieve a degree of "scientific literacy" to enable them to participate effectively as citizens in modern societies.

Palima and Ines (2004) suggest that through science, man has been able to gain much knowledge about nature, and from this knowledge, various applications and devices have been invented and improved. This trend will continue in the foreseeable future, science, after all is a human endeavour.Marinas (2009), cited that the Secondary Science Education Program aims to develop understanding of concepts and key principles of science, science processes, skills and desirable values o make the students scientifically literate, productive and effective citizens (Bureau of Secondary Education, 1998). The Department of Education (DepEd) in the Philippines reported that Science Program of the 2002 Secondary Education Curriculum promotes students' awareness of the relevance of science to life and develops critical and creative thinking as well as skills in problem solving through cooperative learning and teaching of science in an outdoor environment. More than the understanding of science concepts, the emphasis is on the application of these concepts to improve the environment and the quality of life (DepEd, 2002).The role of the freshman teacher teaching General Science is to give the students sciences experiences which provide opportunities for accurate observations and the drawing of conclusions from sufficient evidence. These are necessary to develop concepts that conform to the goals of teaching science information, skills, and habits that are important in dealing with simple everyday problems of personal and social living (Lacambra, 2005). However, one common problem observed and noted by the researcher particularly her class is that majority of her students are very anxious most of the time, especially during recitation and other class activities. As Science teacher, she has been curious to find out what causes her students to be anxious and whether such behaviour contributes to their performance in the subject.

With the above enunciations, educators are encouraged to probe into the scenario if the case is indeed true to the declining performance of the pupils and students in the Philippines for example. The result of the National Diagnostic Test Administered to high school students in 2002 and 2003 show that among these students only eighteen percent (18\%) in English, eight percent (8\%) in Mathematics and ten percent (10\%) in the science passed the competency level. Likewise the results of the trends in Mathematics and Science mean score in 1999 and 2003 were very much lower than the international mean score (bottom 25\% of students). 
The low NAT performance of students particularly in Science in the case of the DepEd is also through in other schools both public and private such as the Naval State University. Specifically, there have been several reasons noted by the teachers relative to students' anxiety in class. As a result, this study mainly focused on the freshmen laboratory high school in which the expectations set by the department was made clear that at the end of the year, the students were expected to be free from anxiety especially in science subject. With the researcher's aim to find ways and means to address the fear and anxiety among students in learning science in order to improve their academic performance in the subject, therefore, this study was undertaken.

\section{OBJECTIVES OF THE STUDY}

The study aimed to find out the factor out the factors related to science anxiety and performance of Freshmen Laboratory High School students of Naval State University.The following were the specific objectives:

1. Determine the profile of the freshmen laboratory high school students in terms of:age; gender;Grade VI Science grade; Entrance exam score; Attitude towards Science.

2. Determine the profile of the parents of the respondents in terms of :number of children; monthly income; educational attainments.

3. Determine the teaching styles of Science teachers as perceived by the respondents;

4. Find out the level of performance of freshmen laboratory high school students in Science;

5. Find out the level of anxiety of the freshmen laboratory high school students.

6. Determine the significant relationship between the students' level of anxiety andgender; Grade VI Science grade; Entrance Exam score; Attitude towards Science.

7. Determine the significant relationship between the students level of anxiety andprofile of parents; teaching style; performance of students.

\section{FRAMEWORK OF THE STUDY}

The ultimate aimed and focus of this study was on the factors related to science anxiety and performance of Freshmen Laboratory High School students of Naval State University, Naval, Biliran.

The concept in determining this study was to look into the profile of the students as to age, gender, Grade VI science grade, results of entrance examination and attitude towards Science, profile of parents in terms of number of children in the family, combine monthly income, educational attainment, the performance of students in Science, the teaching styles of the teachers and the level of anxiety of the students.

Figure 1 portrays the conceptual framework of the study. It conceptualizes the performance level of the students in science and the level of anxiety of the students taking science subjects, the teaching style of the Science teacher (democratic, autocratic and ambivalent) the profile of the parents that contributed to Science anxiety of their children.

Science anxiety of the students was being correlated to profile of parents and teaching styles of their Science teachers with the end view of improving Science performance. Taking also in consideration of the difference of students, level of anxiety to the students' profile, gender, Grade VI Science grade and entrance exam results.

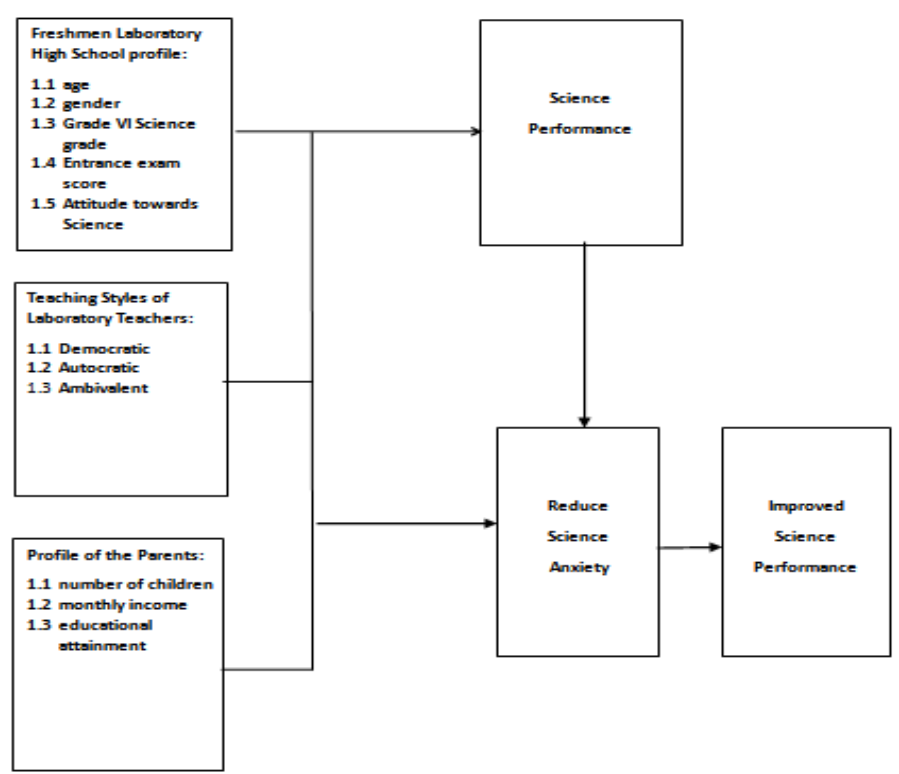

Figure1. Conceptual Framework of the Study 


\section{METHODOLOGY}

This study used the description survey method of research. The researcher used a survey questionnaire with components on the personal profile of the students and parents, teaching style of Science teachers as perceived by the students, and the level of anxiety. Achievement tests were given to the students in determining the performance level for the information needed in gathering data. Then gathered data were tabulated, analysed and interpreted. Certain variables such as students' level of anxiety were correlated to the parents profile and teaching styles by taking into consideration the differences between the profile of students and their level of anxiety.The venue or the locale under which this study was undertaken is at the Lobarotory High School of Naval State University (NSU), Naval, Biliran. The actual place where the study was conducted is in the Laboratory classroom building of the LHS Department.

The subjects involved were the freshman laboratory high school students taking Science during the school year 2010 -2011 and their parents. Universal sampling was used in this study. Out of the three sections 47 was males and 94 were females for a total of 141 respondents. The data were categorized according to the variables of the study. The statistical treatment differed from one variable to another. A more detailed description of how the data were treated is contained in the following discussions: For measuring the three types of teaching styles, which were classified into autocratic, democratic and ambivalent, the total scores obtained by the students for each of ten items for autocratic were computed separately. The teachers' teaching corresponded to the style of which the obtained score of at least five (5) points is higher than the other teaching style. The teachers with their scores in the teaching style did not differ at least five (5) points and were identified as ambivalent. There were teachers who at times used democratic and at other times the autocratic teaching style. The study tested two null - hypotheses. The first was on the relationship between Science anxiety and student profile such as gender, grade VI Science grade, entrance exam and attitudes towards science. The second was on the relationship between level of anxiety and profile of parents' teaching styles and performance of students. Testing the two hypotheses whether there is a relationship between two variables, coefficient of correlation was used. To test the significance error of $r$, t-test was used.

\section{RESULTS AND DISCUSSION}

The presentation, analysis and interpretation of data are based on the objectives of the study. Data are presented as follows: profile of the respondents, teaching styles of the science teachers, performance of the students, the level of anxiety of students in science and relationships of variables.

Profile of the students. The respondents considered in this study were the Freshman Laboratory High School students of Naval State University, their parents and the teachers' teaching science. Table 1 presents the profile of the respondents.

TABLE 1.Profile of the Respondents

\begin{tabular}{|ll|c|c|}
\hline \multicolumn{1}{|c|}{ Variables } & Frequency & Percentage \\
\hline $\mathbf{1 . 1}$ & Age & 3 & \\
& 14 & 88 & 2.17 \\
& 13 & 47 & 63.77 \\
& 12 & $\mathbf{1 3 8}$ & 34.06 \\
\hline & Total & & $\mathbf{1 0 0}$ \\
\hline $\mathbf{1 . 2}$ & Gender & 46 & 33.33 \\
& Male & 92 & 66.67 \\
\hline & Female & $\mathbf{1 3 8}$ & $\mathbf{1 0 0}$ \\
\hline & Total & & \\
\hline Grade VI Science & 16 & 11.59 \\
Grade & 19 & 13.77 \\
& $90-91$ & 40 & 28.99 \\
& $88-89$ & 41 & 29.71 \\
& $86-87$ & 14 & 10.14 \\
& $84-85$ & 8 & 5.80 \\
\hline & $82-83$ & $\mathbf{1 3 8}$ & $\mathbf{1 0 0}$ \\
\hline & To- -81 & Frequency & Percentage \\
\hline
\end{tabular}




\begin{tabular}{|l|c|c|}
\hline 1.4 & & \\
Extrance & & \\
Scomination & 1 & .73 \\
$65-69$ & 2 & 1.45 \\
$60-64$ & 5 & 3.62 \\
$55-59$ & 6 & 4.35 \\
$50-54$ & 12 & 8.7 \\
$45-49$ & 15 & 10.87 \\
$40-44$ & 23 & 16.67 \\
$35-39$ & 33 & 23.91 \\
$30-34$ & 22 & 15.94 \\
$25-29$ & 9 & 6.52 \\
$20-24$ & 5 & 3.62 \\
$15-19$ & 3 & 2.17 \\
$10-14$ & 2 & 1.45 \\
$5-9$ & $\mathbf{1 3 8}$ & $\mathbf{1 0 0}$ \\
\hline Total & & \\
\hline
\end{tabular}

\begin{tabular}{|c|c|c|c|}
\hline Scores & $\begin{array}{l}\text { Qualitative } \\
\text { Description } \\
\end{array}$ & Frequency & Percentage \\
\hline $81-100$ & Very favourable & 8 & 5.8 \\
\hline $61-80$ & Favorable & 33 & 23.91 \\
\hline $41-60$ & Neutral & 73 & 52.89 \\
\hline $21-40$ & Unfavorable & 14 & 10.15 \\
\hline $1-20$ & Very unfavorable & 10 & 7.25 \\
\hline Total & & 138 & 100 \\
\hline
\end{tabular}

As shown in Table 1, of the 138 freshman laboratory high school students of Naval State University, 88 or $63.77 \%$ belonged to the age of 13,47 or $34.06 \%$ belonged to the age of 12 and only 3 or $2.17 \%$ belonged to the age of 14. This may indicate that majority of the students respondents were enrolled in elementary in a right age. As to the gender, 92 or $66.67 \%$ were female and only 46 or $33.33 \%$ were male. This shows that the male dominates the female.

Among the 138 students considered in the study, in terms of the Grade VI science grade, 16 or $11.59 \%$ belonged to category $90-91,41$ 0r $28.99 \%$ were on category $84-85$, and 8 or $5.8 \%$ fell on the category $80-81$. Based on the categorization of Grade VI science grade, the student performance rating is average.

The entrance examination for freshman students was composed of 80 items. Out of 138 students included in this study, only 1 or $0.73 \%$ got a score of 69 considered as the highest score, 33 or $23.91 \%$ belonged to category 30-34. The lowest scored belonged to category 5-9 which was only 2 or $1.45 \%$.

These finding reveal that majority of the freshman laboratory high school students of Naval State University got an average score or only in the median level.

In the attitude towards science, that scores were divided into five categories, namely: those who had the score of 81-100 belonged to the category very favourable, 61-80 belonged to the category favourable, 41-60 belonged the category neutral, 21-40 belonged to the category unfavorableand 1-20 belonged to the category very unfavorable. As presented in Table 1, the highest frequency was 73 or $52.89 \%$ under the category neutral, only 8 or $5.8 \%$ were very favourable, and 10 or $7.25 \%$ were very unfavourable.

It could be gleaned from the results that most of the respondents were in the middle category.

Profile of the parents. This composed of the number of children in the family, family monthly income and educational attainment. This is presented in Table 2.

The study involved the 138 parents of the respondents of the freshmen NSU laboratory high school students. Table 2 presents the number of children in the family profile. Out of 138 families, 2 families had 7 children in the family profile. Out of average children of 4 with a total of 172 or $33.32 \%$. The 8 families had 1 child equivalent to $1.56 \%$. Data show that majority of the 138 families have an average children of 4 . This would imply that family planning is utilized among these families that resulted to lesser number of children in every household.

Table 2. Profile of the Parents

\begin{tabular}{|c|c|c|c|}
\hline $\begin{array}{c}\text { 2.1 Number of } \\
\text { Families }\end{array}$ & $\begin{array}{c}\text { Number of Children } \\
\text { in the Family }\end{array}$ & $\begin{array}{c}\text { Total Number of } \\
\text { Children in the } \\
\text { Family }\end{array}$ & Percentage \\
\hline
\end{tabular}




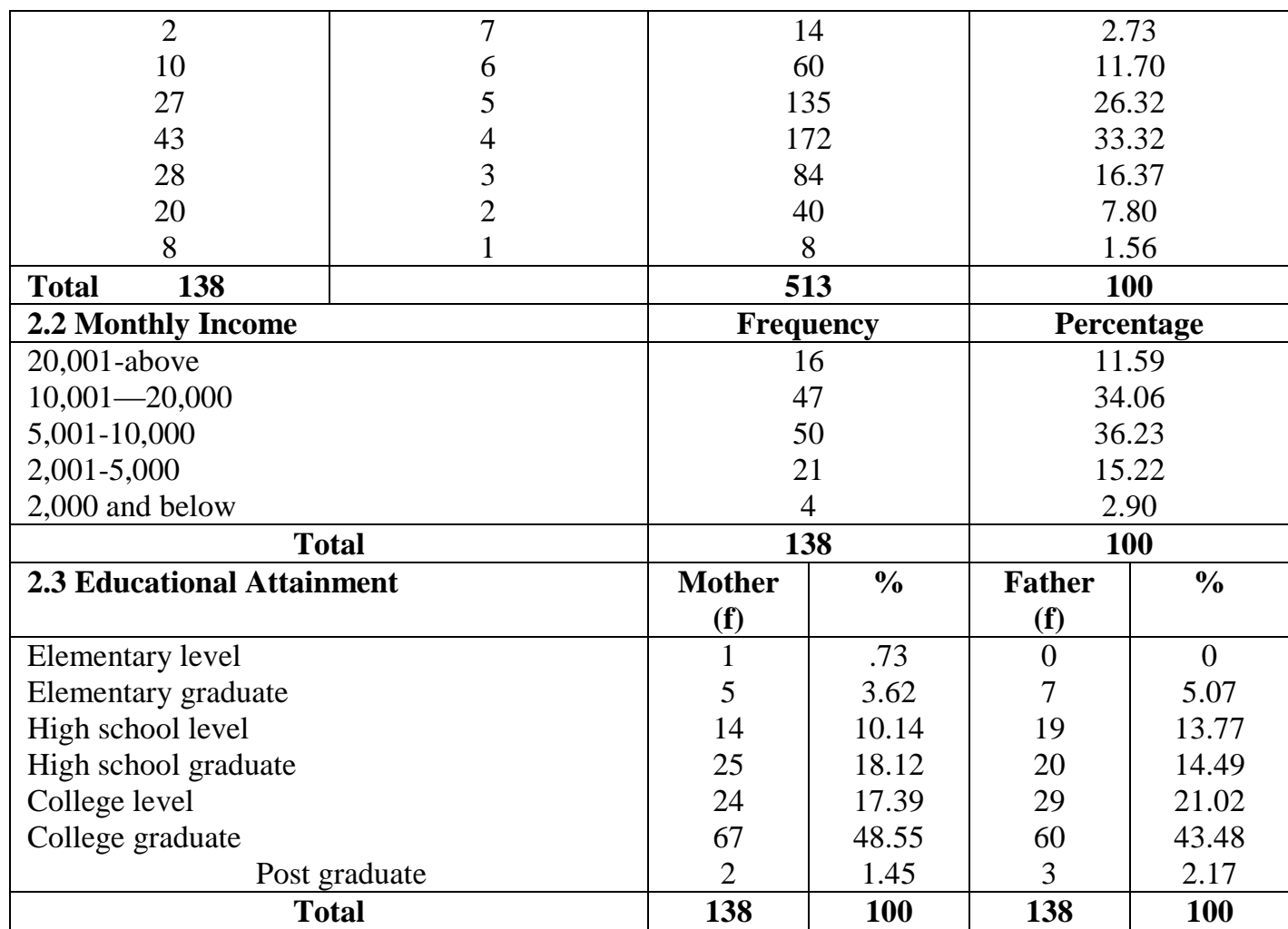

With regards to the monthly income of the family, these were categorized as 2,000 and below, 2001 to 5000 , 5001 to $10,000,10,001$ to 20,001 and above. Out of five categories, two categories had the highest frequency of 50 or $36.23 \%$ for income 5,001 to 10,000 and 4 or $34.06 \%$ for category 10,001 to 20,000 . This implies that majority of the respondents belong to average and above average level of life.

As shown in Table 2, the highest educational attainment of the parents is college graduate and the lowest is elementary level. For the mother of the respondents, 2 or $1.45 \%$ finished post graduate, 1 or . $73 \%$ was elementary level and 67 or $48.55 \%$ were college graduates. This indicates that majority of the respondents' parents are professionals. For the father of the respondents, majority were college graduates, 60 or $43.48 \%$ and 0 for elementary level. This means that the parents consider education very important to them and this also motivates them to send their children to NSU.

Teaching styles of the teacher. To determine teaching style of the teacher, the respondents were exposed to ten (10) statements for autocratic and (10) statements for democratic. The respondents were asked to indicate when he/she always, often, sometimes, rarely and never used democratic or autocratic style in teaching his/her students.

Table 3.Teaching Styles of the Teacher

\begin{tabular}{|c|c|c|}
\hline Teaching Style & Frequency & Percentage \\
\hline Autocratic & 11 & 7.97 \\
\hline Democratic & 69 & 50.00 \\
\hline Ambivalent & 58 & 42.03 \\
\hline Total & 138 & 100 \\
\hline
\end{tabular}

As presented in Table 3, 69 or $50 \%$ of the teachers considered the democratic teaching style, 58 or $42.03 \%$ utilized the ambivalent and 11 or $7.97 \%$ were autocratic. Data show that the teachers teaching science use the democratic style. This implies that in general, the teacher at all times use the democratic way of teaching.

Achievement rating of the students. The actual achievement rating of the NSU Freshman Laboratory High School students were obtained from the results of the examination conducted by the teacher. Based on the categorization, the rating were categorized into outstanding (41-50), very satisfactory (31-40), satisfactory (21-30), needs improvement (11-20) and poor (0-10). 
Table 4.Achievement Scores of the Students

\begin{tabular}{|c|c|c|c|}
\hline Scores & Qualitative Description & Frequency & Percentage \\
\hline $41-50$ & Outstanding & 28 & 20.29 \\
$31-40$ & Very satisfactory & 47 & 34.06 \\
$21-30$ & Satisfactory & 51 & 36.96 \\
$11-20$ & Needs improvement & 10 & 7.24 \\
$0-10$ & Poor & 2 & 1.45 \\
\hline Total & & $\mathbf{1 3 8}$ & $\mathbf{1 0 0}$ \\
\hline
\end{tabular}

Performance rating of the freshman students as reflected in Table 4, 28 or $20.29 \%$ got the highest rating, 51 or $36.96 \%$ for satisfactory and 47 or $34.06 \%$ for very satisfactory with a difference of $2.9 \%$. This only affirms that majority of the students belong to average level or above rating. This also implies that students have lesser fear to their teacher teaching science.

Science Anxiety. The science anxiety of the students is category into five namely: high anxiety, for students with the scores of 76-00, average anxiety for the scores 51 to 75 , low anxiety for the scores 26 to 50 and no anxiety for the scores of 1 to 25 .

Table 5.Science Anxiety Level of the Students

\begin{tabular}{|c|c|c|c|}
\hline Scores & Qualitative Description & Frequency & Percentage \\
\hline $76-100$ & High Anxiety & 12 & 8.70 \\
$51-75$ & Average Anxiety & 85 & 61.59 \\
$26-50$ & Low Anxiety & 35 & 25.36 \\
$1-25$ & No Anxiety & 6 & 4.35 \\
\hline Total & & $\mathbf{1 3 8}$ & $\mathbf{1 0 0}$ \\
\hline
\end{tabular}

As presented in Table 5, 85 or $61.59 \%$ were on the average anxiety, 35 or $25.36 \%$ were on low anxiety, 12 or $8.70 \%$ were on high anxiety and only 6 or $4.35 \%$ were on without anxiety. This implies that the result of the students' anxiety is consonant to the performance of the students.

\section{Relationship of Variables}

This section presents the hypothesis tested in this study. To determine the relationship between variables, the correlation coefficient was used.

Respondents' profile and level of anxiety. Table 6 presents the relationship between the gender profile of the respondents and the level of anxiety of students in science subject. Based on the correlation analysis, the students level of anxiety was highly related to the gender profile of students with $(\mathrm{df}=4 ; \mathrm{r}=0.98)$ which marked a very high correlation. This suggests that the gender profile of the respondents and the level of anxiety are closely related.

Table 6.Relationship Between Students' Level of Anxiety and Gender

\begin{tabular}{|c|c|c|c|c|}
\hline Variables & $\mathbf{R}$ & $\mathbf{C V}$ & $\mathbf{T V}$ & Decision \\
\hline $\begin{array}{c}\text { Students' level of } \\
\text { anxiety to gender }\end{array}$ & .98 & 6.9 & 2.776 & $\begin{array}{c}\text { Ho rejected } \\
\text { Significant }\end{array}$ \\
\hline
\end{tabular}

High correlation, marked relationship at alpha level of significance $(\square)=0.05$

Anxiety level of students and grade VI science grade. The relationship between the anxiety level of the students and their Grade VI science grade is presented in Table 7. The correlation analysis shows that there was a significant relationship between the two variables $(\mathrm{df}=4 ; \mathrm{r}=.89)$. This means that anxiety level of students was highly influence the grade VI science grade.

Table 7.Relationship Between Anxiety Level of Students and Grade VI Science Grade

\begin{tabular}{|c|c|c|c|c|}
\hline Variables & R & CV & TV & Decision \\
\hline $\begin{array}{c}\text { Anxiety level of } \\
\text { Students to Grade } \\
\text { VI grade }\end{array}$ & .89 & 3.87 & 2.776 & $\begin{array}{c}\text { Ho rejected } \\
\text { Significant }\end{array}$ \\
\hline
\end{tabular}

High correlation, marked relationship at alpha level of significance $(\square)=0.05$

Anxiety level students and entrance examination. Table 8 show the relationship between the anxiety level of students and their entrance exam scores. Result of the correlation analysis reveals that the anxiety level of students had a high correlation or marked relationship ( $\mathrm{df}=4 ; \mathrm{r}=.89$ ). This implies that the entrance exam scores of the students is influenced by their anxiety level. 
Table 8.Relationship Between Anxiety Level of Students and Entrance Exam Scores

\begin{tabular}{|c|c|c|c|c|}
\hline Variables & R & CV & TV & Decision \\
\hline $\begin{array}{c}\text { Anxiety level of } \\
\text { students to } \\
\text { entrance exam }\end{array}$ & .89 & 3.9 & 2.776 & $\begin{array}{c}\text { Ho rejected } \\
\text { Significant }\end{array}$ \\
\hline
\end{tabular}

High correlation marked, relationship at alpha level of significance $(\square)=0.05$

The anxiety level of students and the attitude towards science. This is presented in Table 9

Table 9.Relationship Between Anxiety level of Students and Attitude Towards Science

\begin{tabular}{|c|c|c|c|c|}
\hline Variables & R & CV & TV & Decision \\
\hline $\begin{array}{c}\text { Anxiety level of } \\
\text { students to } \\
\text { attitudes towards } \\
\text { science }\end{array}$ & .94 & 4.65 & 3.182 & $\begin{array}{c}\text { Ho rejected } \\
\text { Significant }\end{array}$ \\
\hline
\end{tabular}

High correlation marked, relationship at alpha level of significance $(\square)=0.05$

As shown in the table, the computed $\mathrm{r}$ is .94 which indicates highs correlation. The computed value was 4.65 which is greater than the table value 3.182 at alpha .05 with a degree of freedom 3 . This means that the null hypothesis there is a significant relationship between anxiety level of students and the attitude towards science is rejected. This implies that the students have negative impression to the science subject.

The anxiety level of students and parents profile. The relationship between the anxiety level of student and profile of parents is reflected in table 10. Based on the correlation analysis, there was a significant relationship between the two variables $(\mathrm{df}=4 ; \mathrm{r}=.98)$. This suggest that the anxiety level of students has influence to the parents' profile.

Table 10.Relationship Between Anxiety Level of Students and Parents Profile of the Students

\begin{tabular}{|c|c|c|c|c|}
\hline Variables & R & CV & TV & Decision \\
\hline $\begin{array}{c}\text { Anxiety level of } \\
\text { the students to } \\
\text { parents profile of } \\
\text { the students }\end{array}$ & .98 & .98 & 2.776 & $\begin{array}{c}\text { Ho rejected } \\
\text { Significant }\end{array}$ \\
\hline
\end{tabular}

High correlation marked, relationship at alpha level of significance $(\square)=0.05$

The anxiety level of students and teaching style of teachers. Table 11 shows the relationship

between the anxiety level of students and teaching style of science teachers. The result of the correlation analysis reveals that the level of anxiety had a very high correlation $(\mathrm{df}=1 ; \mathrm{r}=.81)$. The computed $\mathrm{t}$ was .39 which is less than the table value 12.706 at $(\alpha)=0.05$. The hypothesis is accepted and this means that the teaching style of the science teacher does not affect the anxiety level of the students. This implies that the teacher teaching science used the democratic way of teaching.

Table 11.Relationship Between Anxiety Level of Students and Teaching Style

\begin{tabular}{|c|c|c|c|c|}
\hline Variables & R & CV & TV & Decision \\
\hline $\begin{array}{c}\text { Anxiety level of } \\
\text { students to } \\
\text { teaching style }\end{array}$ & .81 & 1.39 & 12.706 & $\begin{array}{c}\text { Ho accepted } \\
\text { Not Significant }\end{array}$ \\
\hline
\end{tabular}

High correlation marked, relationship at alpha level of significance $(\square)=0.05$

The anxiety level of students and science performance. The anxiety level of students and science performance is reflected in Table 12.

Table 12.Relationship Between Anxiety Level of Students and Science Performance

\begin{tabular}{|c|c|c|c|c|}
\hline Variables & R & CV & TV & Decision \\
\hline $\begin{array}{c}\text { Anxiety level of } \\
\text { students to } \\
\text { science } \\
\text { performance of } \\
\text { the students }\end{array}$ & .98 & 7.76 & 2.776 & Ho rejected \\
Significant
\end{tabular}

High correlation marked, relationship at alpha level of significance $(\square)=0.05$ 
Based on the correlation analysis, there was a significant relationship between the two variables $(\mathrm{df}=$ $4 ; r=.97)$. This suggests that the anxiety level of students has influence to the science performance of the students.

\section{CONCLUSIONS}

on the findings of the study, the following conclusions were drawn: The level of anxiety of the freshmen laboratory students is related to their profile especially on the gender which therefore means that the girls are more anxious than the boys. The level of anxiety of the freshmen laboratory high school students is related to tier parents' profile which is due to the latter's high expectation of the former to do well in school and on their performance.The science teachers' way of teaching is very democratic and therefore not related to the anxiety of the students to the subjects. The anxiety level of the students affects their entrance exam performance especially in Science.The students' anxiety level towards Science is on the average level due to the fact that the teacher uses the democratic way of teaching anxiety.The hypothesis that there is no significant relationship between the level of anxiety to gender, Grade VI science grade, entrance exam, parents profile and science performance is rejected and therefore the relationship of variables is highly related.

\section{RECOMMENDATIONS}

In the light of the aforementioned results, the following are recommended. First, the school administration through the leadership and management of the principal of the laboratory high school department of Naval State University should carefully review and evaluate the content and coverage of the entrance examination. Thus, test items should be equally distributed as to the number of areas included such as English, Math, Science and others. Second, the teachers must improvise their methods and approaches by utilizing those that incorporate concrete materials, semi-concrete materials and multi-media presentation particularly in the science subject through the use of constructivism as a philosophy of instruction along with a variety of strategies to motivate and engage students towards active learning. Third, teachers should be absent with thorough information, ideas and knowledge on the recent development reading habits which will be an instrument for intellectual and professional growth and for them to be effective and efficient in teaching the students. Lastly, parallel studies may be conducted especially on finding ways and means in eliminating the fear or anxiety of students related to the teaching and learning of Science.

\section{REFERENCES}

[1] Batomalaque, A.E., (2009). "Basic science development program of the Philippines for international cooperation" Cebu City, University of San Carlos. Retrieved on July 9, 2009 from http://pirun.ku.ac.th/ g4786027/download/content/content111.7.pdf

[2] Department of Education (2009). National achievement test (NAT). National Statistics coordinator Board. Retrieved on December 21, 2010 from http://www.nscb gov.ph

[3] Diamond, J. (1997)."Science anxiety". Retrieved on July 9, 2010 from hhtp://www.people.virginia.edu/ njhua/studysci.htm1

[4] Julianes, M. (2010). State of the higher education: Science teacher education issues and concerns

[5] Limjap, A.A., at.al. Problems and challenges in implementing the new teacher education curriculum (NTEC) in Math education CHED zonal research group in Math, Southern Metro Manila, Philippines.

[6] [Lacambra, L.M.(2005). The modern teacher

[7] [Lapus, J. (2007). "National achievement test (NAT) results "Retrieved on December 21, 2010 from http;///www.nseb.gov.ph

[8] Mallow, J. (1994). "Guide for parents, teachers, counsellors and victims of science anxiety" Retrieved on September 10, 2010 from http:///www.hhpublishing.com/textbooks.science/index.htm

[9] Marinas, B. (2009). "Current trends and main concerns are regards science curriculum". Retrieved on September 7, 2010 from http://www.ibe.unesco.org/curriculum/China/pdf/philippines.pdf

[10] Mesias, F.E. (2002) "Perceptions and attitudes towards science of 13 year old Filipino students." Unpublished Master Thesis University of the Philippines, Diliman

[11] Palima, D.Z. and Ines, M.D.B. (2004). Phoenix science series Physics, Quezon City, Phoenix Publishing

[12] Zulueta, F. and Maglaya (2009). Foundation of Education, National Bookstore 